\title{
How to Survive Selling Scoreboard
}

\author{
Channa Khieng, Mochamad Bruri Triyono, Asnul Dahar Minghat
}

\begin{abstract}
This research located in Sleman, Indonesia, is a case study based on entrepreneurship, called Selling Scoreboard supplies electronic sport scoreboard. This case study chronicled the way taken by the owner's Selling Scoreboard, indicating accurately how the entrepreneurship stretched the surviving stature that it presently detains. Personality can be especially important as the reason that relationship with quality types of produces are building more blocks of producers and market needs. Interview and observation the owner's Selling Scoreboard was achieved to get this data information. The interview and observation helped me to determine the story of business transection from the day it was early instigated just before nowadays. This case study spectacles the progresses, favorable outcome, and bankruptcies of business running, and conclusively contributes tackle or hopeful entrepreneur advice on way to improve his performance to reach his own chances of survival business.
\end{abstract}

Keywords: Entrepreneur, processing business, selling online,

\section{INTRODUCTION}

Economic globalization is affecting industries all over the world. Economic globalization is bringing demand globally [1], [2]. Entrepreneurial activities are changing over time and changing over time and throughout the regions. Large entrepreneur identifies factors that create new startups and explain the difference between entrepreneurs across the country and different period [3]. As an opportunity for owner's Selling Scoreboard with experience-5-year in making electronics sports scoreboard after his graduated vocational school. He tried to lounge his productions on e-business. As a result, the attention and use of e-business effectively became a matter of governance. Interplay is "an economic process, in which all aspects of the business, including physical, financial, and human resources, have taken shape and revolution." Business requires experts to use their skills to improve their performance, and ultimately, growth can be profitable. The incentive to promote entrepreneurship as a motivating factor is the foundation for entrepreneurship in business creation. This is important because motivative can involve how entrepreneurs operate their business and thus can affect the process of investment [6]. At a price based on sales, selling investigators to comprehend and change; sellers' clients' requests to get the benefits, evaluate and link the value of their contribution to the customer level approach to capture some of the displayed values of customers [7]. Cost-based pricing can be achieved

Revised Version Manuscript Received on September 16, 2019.

Channa Khieng, Vocational and Technology Education Program, Yogyakarta State University, DI Yogyakarta, Indonesia.

Mochamad Bruri Triyono, Vocational and Technology Education Program, Yogyakarta State University, DI Yogyakarta, Indonesia.

Asnul Dahar Minghat, Razak Faculty of Technology and Informatic, Universiti Teknologi Malaysia, Kuala Lumpur, Malaysia. survive selling.

using performance-based contracts (PBC), while part of a

contractor's allowance is linked to achieving particular requirements and understanding is linked to achieving specific requirements and understanding and performance standards [8]. Over the years, PBC has been regarded as a model of supply chain management and delivery according to logistics, business model research, service sciences, and legal scholarship. The sales composition includes a rich perception of costly behavior and sales practices, as well as experts who recognize the importance of consumer values [9]. For example, the only "reality" of interest in controlling sales force is that they will create value for customers if they want to succeed. Instead of focusing on customer value, research sales department reached another direction with the sales and sales directed at customers by the coaches [10].

For this case study, I will be considering Mr. JaAn's life in startup his enterprise until now. $\mathrm{He}$ is an Indonesian entrepreneur who established "Selling Scoreboard." His enterprise is already running five-year-old (startup since 2014), and eco-friendly enterprise that outlines and makes a made-to-order electronic scoreboard. I chose his enterprise because of his products and service with acceptable quality and its value with fulfilling all my questions. My aptitudes for business emphasized in my case study, that this enterprise can have an owner, must have been started in an owner's home and must have been originally financed within internal involvement. His life met all accomplishments to push up future based. However, there is a limit to this research: only one owner's enterprise was interviewed and observed. Thus, this case study is briefly narrower scope than another written about owner lives' history of enterprise. This use of only his life business does not allow for contradictions and correlations between lives of entrepreneur's achievement pathway; nevertheless, it is still my hope that entrepreneurs will advance some awareness from some information included with consequent case study and conclusively my research.

It describes seeking a high search for new ways to understand the nature and meaning of daily experiences from his life experiences. The way in which the exploration of the new design methodology is the search process required in this enterprise to understand the user's experience of Selling Scoreboard. To bring this objective of the research on building blocks to understanding how to continue selling electronic scoreboard in Sleman, Indonesia. Through the use of existing theories, this study aims to raise awareness about this subject. The results of this study should be reinforced by vocational education, and so managers must provide information to make strategic decisions. Applying to sell the context with the learning process and the resulting




sales-related consequences of the research approach, with the three questions leading to the study, such as (1) What kind of sale opinions did he dream and hope to do? (2) What factors did he motivate to start and run his business? (3) How did he survive his business?

\section{METHODOLOGY}

To build a case study on the Selling Scoreboard, key data will be collected through direct interview and observations of the enterprise's owner, Mr. JaAn. The first ten questions will be developed and reviewed by the interview protocol to ascertain authorization is needed for this case study research. For additionally total of forty-three questions, I will prepare to make sure that liberal-minded whole effect information is acquired during the interview process. By using the interview results and observation, this study collected data from provider (from interviews by face to face, WhatsApp, and websites) and receivers of learning efficiency perceptions.

ATLAS.ti 7 software was designed to analyze qualitative of the context of documents (i.e. articles, interviews, report), audio (interviews), video, pdf files and geo data with coding, quoting and memo. Using ATLAS.it 7 could be able to analysis and relevance of qualitive data. It is widely used in the analysis of data obtained in interviews and focus groups [11]. In this research, ATLAS.it 7's capabilities are used for coding, quoting, analysis and synthesis of literature from the great attention focused on the indentureship. Coding and sub-coding procedures will be recorded from the transcript of the interview with the following references in Table 1.

Table 1: Coding and sub-coding and references for a case study on selling scoreboard

\begin{tabular}{|c|c|c|}
\hline $\begin{array}{l}\text { Coding and } \\
\text { Sub-Coding }\end{array}$ & Comment & $\begin{array}{c}\text { References } \\
\text { Useful }\end{array}$ \\
\hline $\begin{array}{l}\text { Entrepreneur Life } \\
\text { Startup }\end{array}$ & $\begin{array}{l}\text { New companies can promote embedded networks that rely on the knowledge and } \\
\text { enhance their ability to market intelligence and find solutions. }\end{array}$ & {$[13],[14]$} \\
\hline $\begin{array}{l}\text { Like Working: } \\
\text { Business idea }\end{array}$ & $\begin{array}{l}\text { Identifying and choosing the right opportunities for new business are the most } \\
\text { important abilities of successful entrepreneurship. }\end{array}$ & [15] \\
\hline Business model & $\begin{array}{c}\text { Creating new forms of consumer's engagement in providing trade finance is valued } \\
\text { for the development of new products }\end{array}$ & {$[16]$} \\
\hline $\begin{array}{l}\text { Supporting work } \\
\text { and funding }\end{array}$ & $\begin{array}{c}\text { There is a high potential to look at business opportunities by entering existing or } \\
\text { new markets; } \\
\text { the spread of family funds in this setting, pension funds; and } \\
\text { employee ownership }\end{array}$ & $\begin{array}{l}{[17]} \\
{[18]} \\
{[19]}\end{array}$ \\
\hline $\begin{array}{c}\text { Business process } \\
\text { management }\end{array}$ & $\begin{array}{c}\text { Management and improvement of the process of the organization is an issue } \\
\text { challenge for the organization }\end{array}$ & [20] \\
\hline $\begin{array}{l}\text { Business } \\
\text { improvement }\end{array}$ & $\begin{array}{l}\text { Benefits enhance work efficiency over time and cost control; } \\
\text { Mixed, updated, and synthesis, planning, and communication of the configuration; } \\
\text { Related to the agility of variations and capacity of the resource. }\end{array}$ & $\begin{array}{l}{[21]} \\
{[22]} \\
{[23]}\end{array}$ \\
\hline Business law & $\begin{array}{l}\text { The national government has changed its policy, enforcement, law, and regulatory } \\
\text { policies to benefit from globalization while also attempting to advance its own local } \\
\text { interests. }\end{array}$ & {$[24]$} \\
\hline $\begin{array}{c}\text { Business network } \\
\text { marketing: } \\
\text { E-market } \\
\text { Market-research } \\
\text { Customers-order }\end{array}$ & $\begin{array}{l}\text { Reliability and a set of attributes-how to buy a customer, the length of contact, the } \\
\text { service, the return of the product, and products purchased. }\end{array}$ & $\begin{array}{l}{[1],[20]} \\
{[25]-[28]}\end{array}$ \\
\hline $\begin{array}{l}\text { Quality control: } \\
\text { Product process } \\
\text { Product quality } \\
\text { Product-solve- } \\
\text { problem }\end{array}$ & $\begin{array}{l}\text { Monitoring process and product characteristics for improving product quality. } \\
\text { Meet the demand for high-quality products. } \\
\text { The first solution is revised by different mixed-integer programming models }\end{array}$ & $\begin{array}{l}{[29]} \\
{[30]-[32]} \\
{[20]}\end{array}$ \\
\hline $\begin{array}{l}\text { Business Survival: } \\
\text { Selling survival }\end{array}$ & $\begin{array}{l}\text { Factors such as company size, age or profit have received considerable attention } \\
\text { and the potential effect on product survival; }\end{array}$ & [33] \\
\hline $\begin{array}{l}\text { Product quality } \\
\text { (loyalty) }\end{array}$ & $\begin{array}{l}\text { Information processing capabilities give description like the ability to apprehend, } \\
\text { organize, data / information analysis, and using information; } \\
\text { Short-term treatment (i.e., short sales); } \\
\text { Positively correlated with the company's capability }\end{array}$ & $\begin{array}{c}{[34],[35]} \\
{[36],[38]} \\
{[39]}\end{array}$ \\
\hline
\end{tabular}


This study contains in specific aspect what business academic case studies are the way they are consumed and how to build a display, promotion and publicize them. Even though the composers of this study address on business cases that are utilized in the class-teaching, it can be applied to enterprise academic as case studies. The methods bestowed in this study for case structure and case writing will be widely worked with construction of the Selling Scoreboard case. The attainable purposes for the case study, business structures, cases, and observation are presented herein as clearly deliberated in the formerly noticed papers and indications of the methodology will be used for selling Scoreboard case study [40]. The ultimate element of the case study in enterprise is an exhibit and footnote, usually one to ten pages long. The exhibit allows the author to present information that is not inevitably consistent to the case, but is useful for the reader.

\section{RESULTS AND DISCUSSION}

New companies can promote knowledge-based integration into network and increase market access and availability of solutions [13]. Otherwise, in [18] announced, "Family-fund raising; in this limitation, pensions are not independent and are owned by investment firms, create a family fund, which is often considered a family's fund". In this case study, I would be able to notify the Selling Scoreboard in 2014 established by Mr. JaAn's family saving money and some from loans. He then attempted to surf the online to seek types of the electronic scoreboard that he will be set up to supply in e-market or different social media. Based on his experience:

"... 4-year worked in a company that produced scoreboard, digital clock, moving sign LED display; once opened an Internet Café, and also a sole computer."

In another reason, he could work flexibility with his workplace and his family, so his enterprise was established in a rental house near his family in Sleman, DI Yogyakarta. He kept fighting online to get idea and way to be popular his products, sport scoreboards, as he stated:

"... looked for the idea from the internet and making better basketball scoreboards ... and looking for ways to brighten popular in search engine immediately published to the internet."

With his aspiration that came true for new enterprise according fund from himself and his family, he established Selling Scoreboard to supply electronic basketball scoreboards in Indonesia. Startup digital LED displays with basketball scoreboard in different size based on customers' order with acknowledged his good prototypes, he started launching in potential e-market, as Facebook, Tokopedia, Bukalapak, and Shopee in Indonesia, made detail conversation through WhatsApp (WA). The early result, he got order several types of scoreboards in Jawa island. Kept going on the smooth including sometimes struggling, in this case, that he pushed himself to run up through his work experience. About some technical on installation digital LED basketball scoreboard, he really needed supporting work from his friends in previously. After his enterprise had run enough growing up, he recruited employees who had the expertise and high-quality work from vocational high school (SMK), an internship in practicing install scoreboard. In the vision of potential selling and product quality, he had a commitment to improving his technical skills and his employee, too. A certain component of his personality that sets aside him to develop in entrepreneurship, he had stepped on improving the creative product in customers' using and more order come. In the purpose of easy using and understanding for customers, he had modernized remote controllers and scripture of key function how to control time and scores on the scoreboard. When customers face problems or have questions using remote controllers, he can give instruction through WA or phone call. An identified need, mixed, update, and synthesis analysis, planning, communication of the configuration and implementation of one or more organizational units and relevant parts of their environment in face of organizational complexity [22]; related to the agility of variations and capacity of resource [23]. When consumers really need assistant from him, he can ask from his friends nearby, especially Jakarta. Movement of processing product really connected quality materials and function of programming relating score out on scoreboard based on customers' order that he could contribute and satisfy them. Sometimes he needed more to solve and running these programs after that he took prototype sending through WA. After he got agree from consumers, he completed the installation of program and bagging and sending their requested product with the final budget.

Locating selling his products, he cannot win to get customers in Yogyakarta. As a reason, he could get many customers from Semarang, Sumatra island (Palembang), Kalimantan (Central Kalimantan, South Kalimantan, and some areas nearby), and Sulawesi. Acting in mutual best interests, business decision-making has been achieved with sustainable production from upstream connections to sustainable consumption from downstream connections [37]. $\mathrm{He}$ afflicted to realize the best keyword online since he always investigated to be active online (Blog, Facebook, News, and Forum). Posting the result of the electronic scoreboard, he could early get a small amount of order Nonstop posting his production, it still moved on little famous because it had many competitors in the same products. In [38] had illustrated online sales not just improve mobile business operations. Ways to be popular in search engines, he does not give up to be customers well known, immediately published very good prototype of the scoreboard in Tokopedia, Bukalapak, and Shopee that indicated highest traffic public e-marketplace exceeds in Indonesia. He still focuses on the e-market, because it can be trusted and a set of characteristics related to - how customers acquisition, connecting length, service communication, the activity of product return, and products purchased type on the store in the context of growing online markets [26]. Gradually, because before he got all kinds of (digital display LED) of the order, including customer electronic devices, he just accepted the order of scoreboards. Enabling customers to intervene when his orders are running [28], and achieving customer needs and solutions knowledge [27]. In [31] attributed the importance of product design and processing to the modern industry, practices, efficiency and predictability. That's why 
his product has gained popularity outside his site, but he only welcomes the basketball scoreboards or some new requested similarly that scoreboard types. Product quality control can be the first priority, but his products sometimes face faulty program or damaged shipping (but not all), in the reason unknown using. He attempted its error, so he could know to fix them. Solve problems, he just directed them through WA with video calls, or he asked them to send them back again. The initial solution, revised by a mix of multiplication programs that could lead to specific regional problems, could prevent a better solution to a series of problems [20]. At present, his business is already growing, just surviving with order stability. He can have a well-ordered manner for order in very good condition. By purchasing smooth from the customer, he still tracks everything on his own. The "information" sharing, unrelated to repeated decisions, under the ambiguous information about the temporary winner of the show [35]. Because he did not want to have two heads to control his decision, he was eagerly for himself to make the decision as he said:

"Once there was someone who used to join as a capital supporter, but then I could not choose a business strategy freely, so finally I decided on my own."

The process where the competitive advantage is likely to be uncertain. On the other hand, information processing capabilities give description like the ability to apprehend, organize, data or information analysis, and information usage with understanding in the decision-making context by organization [34]. He could think "The eager to create good products and great service and can be satisfied with his customers firstly." In [39] strongly supported that "Quality products are an important part of the company's core competencies". When customers can enjoy their products, their business is working well. His scoreboard will be bought in his financially stable order. In addition, he has to publish good charts in the e-market. His model will be promoted via e-commerce or the mouth of hundreds of customers in Indonesia. About the national government tax, it has changed its enforcement policies and regulations to gain the benefits of globalization, while also trying to advance its domestic interest [24]. He tried to legalize the government's tax revenue, so he stated,

"I had never taken care of a business permit. Only I ever made a selling statement from selling then report to the branch district and paid the required amount because it was necessary to apply for a loan from the bank. The process of making information was very easy, just needed to know and work with the head of the village, head of the commune, and stamp of the district."

He approached case by case on selling his products online with service acceptable to support consumers be satisfied. On movement of his promotion on type of basket scoreboards, he could get profitable to running his enterprise until now. The keys of his success on selling his products with high quality and service; moreover, customers are easy to use his scoreboard with instructions. Business trust is main key for his enterprise survival because it is good name value. Keeping survive business, he needs to work permit from government for long-term running through tax income.

\section{CONCLUSION}

I concentrated on Selling Scoreboard's pathway to gain the success of my writing case study. Writing this case study assuredly granted me to unify my findings, indicating contrast it was through the interviews, the analyzing of transcription, and observation that answer to my inference is presented. I could find that as a prominent player in the growth and sale progress of Selling Scoreboard, Mr. JaAn's personality of the firm played an important role in the success of the business. As pointed out in its own case, Selling Scoreboard made a significant difference from the breakthrough hobby to a flourishing national business over five-year. From processing in case writing, I first constructed that entrepreneurship gotten success is not from lucky time has encouraged business growth, but he needs working hard. His enterprise, Selling Scoreboard, has evolved from birth to now by way of self-financing, family fund, and loan. Success is not fortunate; it is about choice based our hold on. Every day, entrepreneurs have to make choices, and each individual influences the choice made. Since the day Mr. JaAn decided he wanted to set up the scoreboard until today, he chose the option to make Selling Scoreboard. He is vigorous in his personality; all three dimensions have pushed some attitudes in this enterprise and in his life in general. He persevered in his work when he chose not to fail or reject his purpose. His keen interest to continue searching online, a lesson in web design and photography editing. Without risking Selling Scoreboard will never leave Tokopedia, Bukalapak, and Shopee. Entrepreneurship involves risks and Mr. JaAn is willing to take it. Essentials encourage Mr. JaAn to make some decisions after another Selling Scoreboard leads to the sale successful.

The future research I could to study in entrepreneurship in Cambodia as similar case study written and possible overseas. Road studies will allow repeated observations about the personality of entrepreneurs in different businesses. Through this study, one can know not only what can be successful in the business, but also learn more about what makes the entrepreneur special.

\section{REFERENCES}

1. P. Ueasangkomsate, "Adoption e-commerce for export market of small and medium enterprises in Thailand," Procedia-Social and Behavioral Sciences, 207, 2015, pp. 111-120.

2. N. A. Wahab, L. F. A. Hassan, S. A. M. Shahid, and S. N. Maon, "The relationship between marketing mix and customer loyalty in hijab industry: The mediating effect on customer satisfaction," Procedia Econ. Finance., 37(16), 2016, pp. 366-371.

3. C. Devece, M. Peris-Ortiz, and C. Rueda-Armengot, "Entrepreneurship during economic crisis: Success factors and paths to failure," J. Bus. Res., 69(11), 2016, pp. 5366-5370.

4. F. Hackl, M. E. Kummer, R. Winter-Ebmer, and C. Zulehner, "Market structure and market performance in e-commerce,” Eur. Econ. Rev., 68, 2014, pp. 199-218.

5. V. Bosilj-Vuksic, L. Brkic, and K. Tomicic-Pupek, "Understanding the success factors in adopting business 
process management software: Case studies," Interdisciplinary Description of Complex Systems, 16(2), 2018, pp. 194-215.

6. L. M. M. de Resende, I. Volski, L. M. Betim, G. D. G. de Carvalho, R. de Barros, and F. P. Senger, "Critical success factors in coopetition: Evidence on a business network," Ind. Mark. Manag., 68, 2018, pp. 177-187.

7. E. Munro, "Building soft skills in the creative economy: Creative intermediaries, business support and the 'soft skill gap'," Poetics, 64, 2017, pp. 14-25.

8. J. Liinamaa, M. Viljanen, A. Hurmerinta, M Ivanova-Gongne, H. Luotola, and M. Gustafsson, "Performance-based and functional contracting in value-based solution selling," Ind. Mark. Manag., 59, 2016, pp. 37-49.

9. T. Degenhardt and B. R. Auer, "The 'sell in may' effect: A review and new empirical evidence," North Am. J. Econ. Financ., 43, 2018, pp. 169-205.

10. M. Zhao, C. Dong, and T. C. Cheng, "Quality disclosure strategies for small business enterprises in a competitive marketplace,” European Journal of Operational Research, 270(1), 2018, pp. 218-229

11. M. Stafford, K. Houghton, and D. Stull, "Using ATLAS.TI as a tool to extract and synthesized data obtained in literature reviewing," Value Heal., 12(7), 2009, pp. A388.

12. R. Alasseri, T. J. Rao, and K. J. Sreekanth, "Conceptual framework for introducing incentive-based demand response programs for retail electricity markets," Energy Strateg. Rev., 19, 2018, pp. 44-62.

13. A. Bhalla and S. Terjesen, "Cannot make do without you: outsourcing by knowledge-intensive new firms in supplier networks," Ind. Mark. Manag., 42(2), 2013, pp. 166-179.

14. E. Lundmark and A. Westelius, "Antisocial entrepreneurship: Conceptual foundations and a research agenda,” J. Bus. Ventur. Insights, 10, 2018, pp. 1-6.

15. S. Guercini and B. Cova, "Unconventional entrepreneurship,” J. Bus. Res., 92, 2018, pp. 385-391.

16. G. Pedeliento, C. Bettinelli, D. Andreini, and M. Bergamaschi, "Consumer entrepreneurship and cultural innovation: The case of GinO12,” J. Bus. Res., 92, 2018, pp. 431-442.

17. M. D. Burton, J. B. Sorensen, and S. D. Dobrev, "A careers perspective on entrepreneurship," Entrepreneurship Theory and Practice, 40(2), 2016, pp. 237-247.

18. M. Alda, "A strategic fund family business decision: The pension fund liquidation," Journal of Business Research, 91, 2018, pp. 248-265.

19. N. B. Arfa, M. Karmani, and D. Labaronne, "Antecedents of hedge fund activism in French listed target firms," Res. Int. Bus. Financ., 42, 2017, pp. 1315-1326.

20. B. Niehaves, R. Plattfaut, and J. Becker, "Business process management capabilities in local governments: A multi-method study," Gov. Inf. Q., 30(3), 2013, pp. 217-225.

21. J. Abreu, P. V. Martins, S. Fernandes, and M. Zacarias, "Business processes improvement on maintenance management: A case study," Procedia Technol., 9, 2013 , pp. 320-330.

22. M. Geissdoerfer, D. Vladimirova, and S. Evans, "Sustainable business model innovation: A review," J. Clean. Prod., 198, 2018, pp. 401-416.

23. F. S. Tsai, C. H. Lin, J. L. Lin, I. P. Lu, and A. Nugroho, "Generational diversity, overconfidence and decision-making in family business: A knowledge heterogeneity perspective," Asia Pacific Manag. Rev., 23(1), 2018, pp. 53-59.

24. P. H. Gaughan and R. G. Javalgi, "A framework for analyzing international business and legal ethical standards," Bus. Horiz., 61(6), 2018, pp. 813-822.
25. J. A. Abdulridha and A. M. Hussein, "The role of leadership in strategic management," Int. J. Res., 5(5), 2017, pp. 99-106.

26. X. Yang, G. Cai, Y. J. Chen, and S. J. S. Yang, "Competitive retailer strategies for new market research, entry and positioning decisions,” J. Retail., 93(2), 2017 pp. 172-186.

27. W. Chang, "The joint effects of customer participation in various new product development stages," Eur. Manag. J., 37(3), 2019, pp. 259-268.

28. V. Giannikas, D. McFarlane, and J. Strachan, "Towards the deployment of customer orientation: A case study in third-party logistics," Comput. Ind., 104, 2019, pp. 75-87.

29. X. Xiao, W. Jiang, and J. Luo, "Combining process and product information for quality improvement," Int. J. Prod. Econ., 207, 2019, pp. 130-143.

30. R. Wagner, B. Haefner, and G. Lanza, "Function-oriented quality control strategies for high precision products," Procedia CIRP, 75, 2018, pp. 57-62.

31. M. Peruzzini, F. Grandi, and M. Pellicciari, "How to analyze the workers' experience in integrated product-process design,” J. Ind. Inf. Integr., 12, 2018, pp. $31-46$.

32. G. Li, M. Reimann, and W. Zhang, "When remanufacturing meets product quality improvement: The impact of production cost," Eur. J. Oper. Res., 271(3), 2018, pp. 913-925.

33. J. M. Ortiz-Villajos and S. Sotoca, "Innovation and business survival: A long-term approach," Res. Policy, 47(8), 2018, pp. 1418-1436.

34. G. Cao, Y. Duan, and T. Cadden, "The link between information processing capability and competitive advantage mediated through decision-making effectiveness,” Int. J. Inf. Manage., 44, 2019, pp. 121-131

35. T. Wu and A. Seidmann, "Can irrelevant benchmark information help when making business decisions under uncertainty? An empirical investigation of the newsvendor game," Ukr. Math. J., 53(5), 2017, pp. 701-718.

36. Y. Jiao, M. Massa, and H. Zhang, "Short selling meets hedge fund 13F: An anatomy of informed demand," J. Financ. Econ., 122(3), 2016, pp. 544-567.

37. M. Gong, A. Simpson, L. Koh, and K. H. Tan, "Inside out The interrelationships of sustainable performance metrics and its effect on business decision making: Theory and practice," Resources, Conservation and Recycling, 128 , 2018, pp. 155-166.

38. S. Johnson, J. M. Matthes, and S. B. Friend, "Interfacing and customer-facing: Sales and marketing selling centers," Industrial Marketing Management, 77, 2019, pp. $41-56$

39. H. He and Z. Yu, "Product quality, incomplete contract and the product cycle," Int. Rev. Econ. Financ., 53, 2018 pp. 160-167.

40. L. M. Arrom, J. Huguet, C. Errando, A. Breda, and J Palou, "How to write an original article," Actas Urol. Esp., 42(9), 2018, pp. 545-550. 